\title{
PRICING OF ALBERTA'S OIL
}

\section{PETER TYERMAN*}

The history, functions and scope of the Alberta Petroleum Marketing Commission are studied. In addition, the practices and procedures of the A.P.M.C. are discussed, especially the pricing and marketing aspects. Finally, the Petroleum Administration Act is looked at in some depth. The Edmonton Terminal Price, Export Tax and the enforcement of the Petroleum Administration Act are dealt with by the author.

\section{BACKGROUND}

Until 1973 Canada's oil prices were determined by the prevailing world price for oil. ${ }^{1}$ The Alberta wellhead price was calculated by taking the estimated cost of foreign oil shipped to Chicago less deduction for shipping, gathering and quality. ${ }^{2}$ In 1973 O.P.E.C., Organization of Petroleum Exporting Countries, began increasing its prices until, by January 1, 1974 the posted price of Arabian light "marker" crude, the standard against which all oil quality is measured, reached $\$ 11.65$ per barrel, up from $\$ 5.11$ per barrel ${ }^{3}$ previously. The F.O.B. selling price of "marker" crude was $\$ 10.46$, of which the selling government received $\$ 7.11$ per barrel in royalties, taxes and participation formulae. ${ }^{4}$ The jump in foreign oil prices brought corresponding price increases in Canada and the U.S. until the Canadian and U.S. governments moved to control their respective domestic oil prices. ${ }^{5}$

On September 4, 1973 Prime Minister Trudeau froze the average wellhead price of Alberta crude oil at $\$ 3.80$ a barrel. ${ }^{6}$ The Prime Minister promised a return to world price at the end of the proposed five month freeze. ${ }^{7}$ The world price took some very dramatic jumps between September and February ${ }^{8}$ when the freeze was to end and the return to world prices for Alberta oil has not been achieved some two and a half years after the initial price freeze.

The National Energy Board, N.E.B., must approve all exports of Canadian oil to the U.S. ${ }^{9}$ In September 1973 the N.E.B. refused applications to export oil to the U.S. for the month of October 1973, on the ground that the proposed export price based on the frozen wellhead price was $\$ .40$ too low to be in the best interests of Canada. ${ }^{10}$ The N.E.B. had determined that Canadian oil sold for export to Chicago at the frozen wellhead price would cost $\$ .40$ less than Arabian crude when both

\footnotetext{
- Graduating student, Class of 1976, Faculty of Law, University of Alberta.

1 Edmonton Journal, Sept. 5, 1973.

2 Commission Interview, February 5, 1976, with D. W. Minion, Chairman of the Alberta Petroleum Marketing Commission and several employees of the Commission in attendance.

3 First Annual Report of the Alberta Petroleum Marketing Commission (1975), p. 15.

- Id.

S Supra, n. 1.

- Id.

i Id.

- Supra, n. 3.

- National Energy Board Act, R.S.C. 1970, at 8. 83.

iv Oil \& Gas Journal, Sept. 24, 1973, at 90-91.
} 
were laid in to Chicago. ${ }^{11}$ On September 13 Donald MacDonald, then Minister of Energy, Mines and Resources, announced a $\$ .40$ a barrel tax on all oil exported from Canada commencing Oct. 1, 1973.12 The N.E.B. then invited exporters to reapply for October export permits with the proposed prices including the $\$ .40$ tax. The reapplications were approved. ${ }^{13}$

The export tax touched off a power struggle between the federal government and the governments of Alberta and Saskatchewan over control of provincial oil and gas resources, and the revenues they generate. ${ }^{14}$ The export tax appropriated money to the federal treasury that would have been split between the provincial treasuries and the oil companies if the wellhead price for exported oil had been allowed to rise rather than the export tax being imposed. ${ }^{15}$ Alberta Premier Peter Lougheed charged Ottawa with discrimination and bad faith and threatened to fight the federal government with every weapon at his disposal. ${ }^{16}$ Lougheed saw the export tax as more than an appropriation of revenue from the provincial treasury. He saw it as a move to grab control of resources from the provinces. ${ }^{17}$

Alberta Premier Lougheed and Federal Energy Minister McDonald met in Calgary during October, 1973 to discuss their respective positions on the petroleum export tax and petroleum pricing generally. The meetings failed to produce any kind of agreement between the two levels of government, ${ }^{18}$ and Premier Lougheed's next move was to call the Alberta Legislature into special sitting commencing December 3, $1973 .{ }^{19}$

The session became known as the "Energy Session" and enacted several bills ${ }^{20}$ designed to strengthen Alberta's position in its dispute with Ottawa over control of Alberta's petroleum resources. ${ }^{21}$ Alberta's strongest constitutional position is as the owner of the resources with a proprietary right to control their disposition under section 92(5) of the B.N.A. Act. 22 The legislation passed during the session was drafted with a view to putting Alberta's energy legislation on its strongest constitutional position. ${ }^{23}$ For example, Alberta's petroleum marketing

\footnotetext{
"Id.

12 Id.

is Id.

"McDonald, W. A.. "Resource Tax Mess Could be Sorted Out by Federal Power", The Financial Post, November 1, 1975, at C.5.

is $l d$.

16. Edmonton Journal, September 14 and November 2, 1973.

17 Id.

is Edmonton Journal, Oct. 5, 1974.

19 Edmonton Journal, Nov. 2 and 3, 1973.

20 The Bills passed by the Energy Session include Bill \#53-Arbitration Amendment Act, 1973-makes the commodity value of natural gas a major factor in determining its price. Bill $\# 93-$ Freehold Mineral Taxation Act. Bill \#94-Mines and Minerals Amendment Act, 1973-eliminates maximum royalty, makes royalty payable in kind at the point of production, requires delivery of all royalty barrels to the Alberta Petroleum Marketing Commission, requires lessee to sell his share of Crown oil through the A.P.M.C. Bill $495-$ The Petroleum Marketing Act-establishes the A.P.M.C. and gives it the powers to receive and sell all oil from Crown leases. Bill \#96-Gas Resources Preservation Amendment Act, 1973-restricts the application of the Gas Resources Preservation Act to Crown natural gas.

21 Elma Spady. Solicitor for the Alberta Department of Energy and Natural Resources; interview January 19, 1976.

22 Provided that the province can persuade the courts that oil once produced subject to a Crown lease is still subject to control as part of the Crown's right to control disposition of land and s. 92(5) of the B.N.A. Act, the section gives the provinces powers to legislate in areas that they would otherwise be barred from legislating in. See Smylie v. The King (1900) 27 O.A.R. 172, and Brooks-Bidlake and Whittall Lid. v. A.G. British Columbia. 1923 A.C. 450.

2. Supra, n. 21.
} 
apparatus established under the Petroleum Marketing Act, S.A. 1973, c. 96, distinguishes between sales of the Crown's royalty share of petroleum, Part 2 of the Act, sales of Crown lessee's share of the petroleum, Part 3 of the Act, and sales of all petroleum including freehold which is covered by Part 4 of the Act and not yet proclaimed. The P.M.A. distinguishes between freehold and Crown oil because the Crown has no special right to control the disposition of freehold oil as it might have with respect to Crown oil under section 92(5) of the B.N.A. Act. The province could be in a weaker position with respect to a constitutional fight with Ottawa if they included freehold minerals in their marketing scheme.24 Freehold minerals were included in the marketing scheme proposed to the Federal-Provincial First Ministers' Conference in January, $1974,{ }^{25}$ by Alberta and this is why Alberta made provisions in the Petroleum Marketing Act for such a scheme. Since the conference rejected Alberta's proposal, it is unlikely that Part IV of the P.M.A. will ever come into force. ${ }^{26}$ The Act distinguishes between the Crown's royalty share and the lessee's share of petroleum in the P.M.A. because under the lease the lessee's share belongs to the lessee as soon as it is pumped out of the ground. ${ }^{27}$ Therefore, in order to make the argument that the lessee's share of oil was still subject to the proprietary control of the Alberta government under its section 92(5) powers Alberta had to make it a condition of the lease which grants the lessee's ownership right that the lessee's share of petroleum be sold through the A.P.M.C. ${ }^{28}$ Thus, section 170.2 of the Mines and Minerals Act was enacted. ${ }^{29}$ The Crown has the right to take its royalty in kind. This right was exercised by section 170.1 of the Mines and Minerals Act. ${ }^{30}$ Thus, the P.M.A. is drafted to take advantage of and conform to Alberta's proprietary rights with respect to Crown petroleum produced in Alberta.

The Freehold Minerals Taxation Act, S.A. 1973, c. 89 was enacted to complete the distinction between freehold and Crown lease mineral rights with respect to the legal characterization of each and the methods of raising revenue from each. The Act was passed in order to make Alberta's Mineral Tax Laws consistent with Alberta's argument for provincial proprietary rights over the disposition and pricing of provincial Crown resources. ${ }^{31}$ In 1972 when Alberta revised its royalty structure and its taxation of mineral rights, both the lease interest in minerals in situ granted pursuant to Crown leases, and the freehold interests in minerals in situ were taxed under the Minerals Taxation Act, 1972, S.A. 1972, c. 67, sections 1(k), 3, 5, 17. Under the Freehold Minerals Taxation Act sections 1(h), 6, 7, and 14 only freehold interests in minerals in situ are subject to tax. The problem with the 1972 tax law is that it treated Crown lessee's interests in the minerals in the same way that proprietary freehold rights were treated. This lends support to the argument that the interest granted under the petroleum and natural gas lease was a proprietary interest and therefore the Crown has

2 Id.

2s Edmonton Journal, Jan. 24, 1974, at 6.

26 Supra, n. 21.

27 The lease in the nature of a profit-a-prendre grants ownership of the oil to the lessee as soon as it is recovered from the ground, except that portion of the petroleum which is the Crown royalty share.

28 Supra, n. 21.

29 Mines and Minerals Amendment Act, 1973, S.A. 1973, c. 94.

.0 Id.

31 Supra, n. 21. 
disposed of its interest in the petroleum produced from Crown lands via the lease. If the Crown is held to have completely disposed of its interest in the petroleum produced from the leased lands under the terms of the lease, except for royalties, then section 92(5) of the B.N.A. Act would not apply to the petroleum and Alberta would have a marketing scheme not a scheme to protect its proprietary interests. A simple marketing scheme without the color of proprietary interest under 92(5) would be vulnerable to attack as infringing the Federal Trade and Commerce power and most likely would be struck down. ${ }^{32}$ It was necessary for Alberta to restrict its Mineral Tax to freehold minerals and to rely solely upon its royalty provisions to raise revenue from Crown minerals.

The primary objectives of the "Energy Session" were first to recover the revenues lost to the federal treasury under the export tax on crude oil and second to assert the province's control over the pricing and marketing of its petroleum resources. ${ }^{33}$ In order to achieve these objectives, Alberta amended the Mines and Minerals Act, R.S.A. 1970, c. 238 and enacted the Petroleum Marketing Act, S.A. 1973, c. 96. Section 142.1 was added to the Mines and Minerals Act in order to remove the final legal barrier in the way of Alberta's proposed royalty increases (see Appendix A). Section 170.1 was added to the Mines and Minerals Act to require all Crown lessees to make payment of royalties in kind to the Alberta Petroleum Marketing Commission. ${ }^{34}$ Section 170.2 was added to the Mines and Minerals Act requiring that the lessee's share of petroleum be delivered to and sold through the Alberta Petroleum Marketing Commission. The Petroleum Marketing Act established the A.P.M.C., Alberta Petroleum Marketing Commission and sets its terms of reference. The Commission has the power to set prices, to sell and to set the terms of sale for all petroleum produced form Crown lands in Alberta (discussed in more detail later). The Commission also effectively controls the pricing and marketing of freehold petroleum due to the fact that $80 \%$ of Alberta's petroleum is produced from Crown lands. ${ }^{35}$ No producer of freehold oil could sell much oil for very long at a price higher than the A.P.M.C.'s price.

Alberta was able to deal with Ottawa from a much stronger position as a result of the legislation brought in during the Energy Session. At two Conferences in January and March of 1974, Prime Minister Trudeau and the premiers of the two provinces were able to reach agreements more or less satisfactory to all which resulted in increased wellhead prices for crude oil commencing April 1, 1974.36 While negotiations to raise the wellhead price of crude oil were in progress, the Alberta government was preparing its new royalty provisions. These went into effect April 1, 1974, as A.R. 93/74 and A.R. 94/74, at the same time the price of crude oil was increased.

The new royalty calculations in effect pursuant to section 2 of the regulations (see Appendix A) are composed of two basic elements. The first element is equivalent to the old royalty calculation under the 1972 agreement with industry whereby the maximum effective royalty rate

\footnotetext{
12 The recent cases in the Supreme Court of Canada tend to hold that provincial marketing schemes infringe the trade and commerce power and therefore should be struck down.

supra, n. 2

34 Mines and Minerals Amendment Act, 1973, S.A. 1973, c. 94.

ss Supra, n. 21.

:t Edmonton Journal, January 24 and April 3, 1974.
} 
was approximately $22 \%^{37}$ (this is the $S$ factor in the royalty formula in schedule $B$ of the regulations). Added to this component is a new factor which takes into account any price increases for crude oil and increases the Crown's royalty as the price of oil is increased. (This is the KS (AB)/A part of the formula in schedule B of the regulations.) The effective maximum rate of this calculation is approximately $39 \%$ of production on oil other than new oil, as defined by section 2 of the regulations, and approximately $27 \%$ on new discoveries or enhanced recovery. ${ }^{38}$ The increase in royalties would have reduced the federal government's tax revenue from oil companies by reducing the oil companies' taxable income had the 1974 Federal Budget not radically altered the corporate tax structure as it relates to the oil industry. Alberta's increased royalty take and increased wellhead prices gave the Alberta Treasury about $\$ 1$ billion additional revenue annually.39 Alberta's intention had been to gain its revenue increase at the expense of the federal treasury through the producing oil companies. ${ }^{40}$ The federal government's response was to change the tax rules affecting producing oil companies and thus regain its share of the price increase. ${ }^{41}$

In May, 1974, Finance Minister John Turner brought down the Federal Budget with several changes proposed for the resource sector of the economy. ${ }^{42}$ The major proposals that effected the petroleum industry are as follows: (1) It raised the basic tax rate to $50 \%$ less abatements and incentives; (2) Royalties, taxes and other like payments to provincial governments would no longer be recognized as a deduction in computing income for tax purposes; instead a $10 \%$ abatement would be given for petroleum profits, which together with the normal provincial abatement would give a $30 \%$ federal tax rate on petroleum profits; (3) The rate of write-offs for exploration and development expenditures was to be cut to $30 \%$ from $100 \%$ per annum. The federal tax measures combined with provincial royalties and taxes threatened to take all the profits out of oil production. ${ }^{43}$

The minority Liberal government was defeated over the budget but won a majority of the new house. When the 1974 budget was brought before the house again in November, many of the proposals with respect to the petroleum industry introduced in the May budget were reintroduced. 44 The most damaging proposal dissallowing deduction of royalties and provincial taxes was brought back but the blow to the oil industry was softened by changes to some other proposals. ${ }^{45}$ The abatement for 1975-1976 was increased so that the effective federal tax rate in 1976 and after would be $25 \%$, and the write-off for exploration expenditures was maintained at $100 \%$ per annum while the write-off on development expenditures was reduced to $30 \%$ per annum. ${ }^{46}$ These

w7 This is based on production of 4,000 barrels of oil per month from each well, in any event the maximum rate that is mathematiclaly possible approaches $25 \%$.

in These calculations are also based on 4,000 barrels per month.

as Supra, n. 2.

su Supra, n. 14.

1 Id.

12 (May 6. 1974) H.C. Deb., p. 2079

ailweek, Nov. 25, 1974, at 3 .

4 Id.

15 Budget Speech of Honourable John Turner, Minister of Finance, Monday, November 18, 1974, published by the Ministry of Finance, at 13-15. Supplementary Information, Budget Canada, Monday, November 18, 1974. published by Ministry of Finance, at 5 .

16 Id 
concessions were small but they did allow some breathing room for the oil producer. ${ }^{47}$ The Alberta Government responded by adjusting its royalty provisions to give a lower effective royalty rate of $35.2 \%{ }^{48}$ (See Appendix A.) Even with these small concessions from the two levels of government, the oil industry was put in a tight financial squeeze. ${ }^{49}$

While the federal and provincial levels of the Canadian government were fighting to grab as much as they could out of the increased world price the U.S. was permitting the price on new oil to increase as the world price increased. ${ }^{50}$ The U.S. distinguished between old oil, which was defined as oil whose recovery was economically feasible at the old oil prices, and "exempt" oil which includes new discoveries and enhanced recovery from existing pools which would not have been economically feasible at the price for "old" oil.51 The attitude of the U.S. government is explained by the fact that the U.S. was and still is a net importer of oil and therefore was trying to encourage the industry to explore for new fields and to spend money to recover more oil from existing fields. ${ }^{52}$ The incentives for exploration, in the U.S. combined with the tax, royalty, and prices squeeze in Canada caused a massive exodus of drilling and exploration companies and equipment from Canada during 1974 and the first part of $1975 .^{53}$

Alberta's Exploratory Drilling Incentive Regulations ${ }^{54}$ enacted in 1972 along with the 1972 royalty regulation revisions and the Mineral Taxation Act, 1972 were negated by Alberta's actions in the federalprovincial dispute over resources.55 Under section 9 of the regulations the credit established under section 7 for drilling a wildcat incentive well could be applied in satisfaction of monies payable pursuant to dispositions to which part 5 of the Mines and Minerals Act applies or in satisfaction of taxes levied under the Mineral Taxation Act, 1972 and becoming due and payable between January 1, 1973 and December 31, 1979. Payments under part 5 of the Mines and Minerals Act include lease rentals, ${ }^{56}$ penalties for extending the time for commencement of drilling, ${ }^{57}$ and the payment of royalties. ${ }^{58}$ After March 1, 1976, when the Commission began taking royalty in kind, ${ }^{59}$ the drilling credits could no longer be applied to satisfy royalty payments because there was no cash payment to satisfy. Since the Freehold Mineral Taxation Act restricted the Mineral Taxation Act, 1972 to the 1973 taxation year, ${ }^{60}$ this application of drilling credits disappeared on January 1, 1974. Since the main use of the credits would have been to offset royalties and taxes there was not much incentive left in the incentive regulations after the 1973 Energy Legislation was in force.

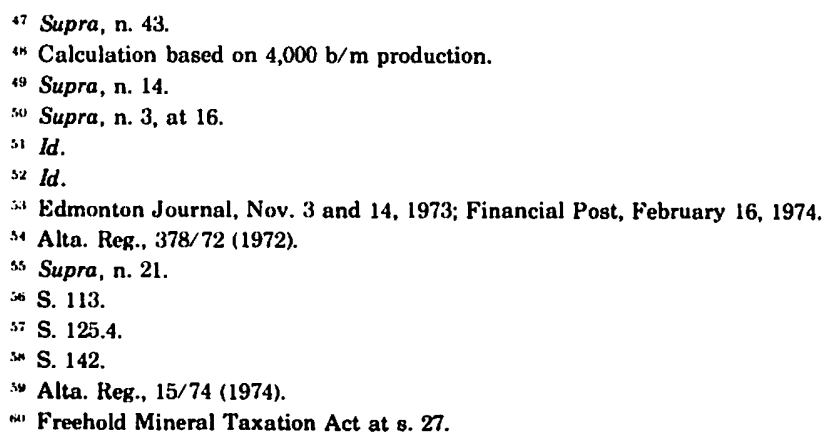


In February, 1974 Alberta established new Exploratory Drilling Incentive Regulations. ${ }^{61}$ These regulations emphasized deep drilling programs by giving larger incremental credits for drilling to greater depths. ${ }^{62}$ These incentives suffered the same basic problems as the old incentives ${ }^{63}$. They are applicable to: (a) monies payable under part 5 of the Mines and Minerals Act, (only application fees and rentals on leases are available); (b) monies payable pursuant to section 40 of the Mines and Minerals Act, (interest and arrears); (c) taxes levied under the Freehold Mineral Taxation Act, and becoming due and payable between January 1,1974 and Decamber 31,1979 . Since the royalty and tax burden on any production was substantial, there was not much incentive to spend money drilling for oil just to earn credits.64 The credits could not be applied to satisfy royalties which were still the largest burden on the oil companies. ${ }^{65}$ Unless there were a chance of some substantial economic returns from any new oil found, there would not be much incentive to drill even though the new drilling credit system was much more advantageous than the old system. ${ }^{6}$

The large deep drilling rigs began returning to Alberta in 1975 and an increased amount of deep drilling activity is currently under way in the Alberta foothills region. ${ }^{67}$ Prospects of major new discoveries are considered good. Increases in the average wellhead price of Alberta oil, ${ }^{68}$ lower royalty rates on new oil, ${ }^{69}$ the new drilling incentive program for deep drilling and an incentive program for seismic work ${ }^{70}$ combined with poor results in the U.S. are the major reasons for the resumption of drilling activity in Alberta. ${ }^{71}$ A possible hidden benefit to Alberta of the exodus of drilling activity is that a lot of old, small rigs left and have not returned. The large rigs necessary for deep drilling projects are still in short supply in Alberta. This will only hamper exploration in the foothills' deep horizons where any major new discoveries will be made. ${ }^{72}$

Alberta's actions throughout the struggle with Ottawa had three main objectives:73 (1) to keep control over the provinces' resources, (2) to get as high a price as possible for Alberta's oil, (3) to encourage the oil industry to search for new oil discoveries in Alberta. Ottawa's actions through the dispute have been aimed at four objectives ${ }^{74}$ with emphasis on the first two: (1) a single price for oil in Canada, (2) to shelter Canadian consumers from high world oil prices, (3) to encourage exploration for and development of new sources of oil in Canada, (4) to make Canada self-sufficient in oil in the future. The main area of dispute between the Alberta government and Ottawa was the price to be paid for Alberta oil. Alberta had no real quarrel over the idea of a single domestic price for

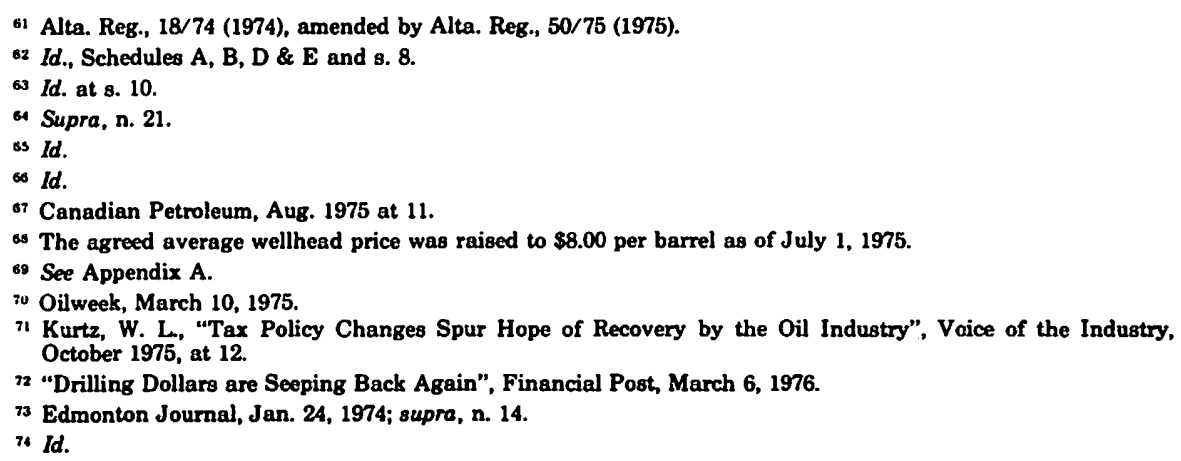


oil, only as to the level at which that price should be set. ${ }^{75}$ Alberta was in agreement with Ottawa that exploration and development activities should be encouraged but felt that the best way to encourage exploration and development work was by offering the oil companies a bigger financial return in the form of increased prices and revenue for new oil..$^{76}$ Ottawa felt that keeping the price down to protect consumers was more important, at least initially. ${ }^{77}$ Now that the level of Canada's oil reserves is falling and the N.E.B. has predicted a shortfull of domestic oil production by $1982^{78}$ the federal government is starting to put more emphasis on exploration..$^{79}$ The average Alberta wellhead price of oil was increased by federal-provincial agreement to $\$ 6.50$ per barrel on April 1, $1974^{80}$ and to $\$ 8.00$ a barrel on July $1,1975.81$ These prices were largely forced on Ottawa by economic factors, which I will illustrate later, and by pressure from the Alberta government. Ottawa is committed to pricing oil from the tar sands at world levels when Syncrude comes on stream in 1979,82 but in the meantime they still appear to be intent on a program of staged in price increases to protect the consumer as long as possible. ${ }^{83}$ Energy Minister A. Gillespie recently announced ${ }^{84}$ that the federal government plans to monitor the spending of the oil companies more closely in the future to ensure that future price increases for Canadian oil will be spent on exploration. This announcement hints at further domestic price increases in the near future and details the effect of current federal government tax incentives for exploration activities..$^{85}$ A one dollar a barrel increase in oil prices would result in the companies receiving $\$ .25$ while the provinces would take $\$ .48$ and Ottawa $\$ .27$, but if the companies were to reinvest $\$ .50$ of the increase they would get $\$ .44$ and Ottawa $\$ .03$ of a one dollar increase. ${ }^{86}$ The consensus of industry opinion is that the wellhead price in Alberta will increase by at least $\$ 1.50$ to $\$ 2.00$ a barrel on July 1, 1976. Generally, Ottawa seems to be shifting its emphasis toward encouraging new production of oil to meet the predicted 1982 shortfall and in that regard it is contemplated price increases to encourage new exploration and new development work. ${ }^{87}$

Ottawa, as part of its policy of achieving self-sufficiency in oil for Canada, proposed the construction of an oil pipeline to service the Montreal area with Western Canadian crude. ${ }^{88}$ The proposal to build a pipeline from Toronto to Montreal was first made in the 1950's but was

73 Id.

is ld.

ild.

;N Energy Analects, Oct. 10, 1975, at 6; Energy Analects, November 29, 1974, at 1; National Enerky Board, Report to the Minister of Energy, Mines and Resources, "In the Matter of the Exploration of Oil", Oct. 1974, at 6-4, "The board is forecasting that by 1982 there will not be enough crude oil produced in Canada to meet the Canadian market demands which are not served by Canadian oil production, plus some $250 \mathrm{M}$ b/d for Montreal."

79 Edmonton Journal, March 31, 1976.

so Energy Analects, Oct. 10, 1975.

wi Id.

*2 West, John, Supply \& Transportation Division, Gulf Oil Canada; interviewed in Calgary, February 6, 1976.

s.s Supra, n. 10 at editorial.

nt Supra, n. 79.

ss Income Tax Act, 365, ITR Part XII, \& Part XII.1.

m6 Supra, n. 84-

a7 Id.-Mr. Gillespie's announcement appears to be leading up to a large oil price announcement aimed at spurring exploration activity. (The price of oil is to be raised $\$ 1.50$ per barrel as of July 1,1976 to $\$ 9.00$ per barrel, Edmonton Journal, May 18, 1976.)

** Edmonton Journal, March 21 and April 1, 1976. 
rejected at that time because foreign oil supplies could be landed in Montreal cheaper than Alberta or Saskatchewan oil.89 Thus, the Interprovincial Pipeline Company only built its lines as far as Toronto. Ontario was serviced from the west and Quebec and the Maritimes were serviced from foreign sources of oil.s0 Now that foreign oil is more expensive Quebec has agreed to use Alberta and Saskatchewan oil and the pipeline from Toronto to Montreal is nearing completion, the lines are awaiting approval of the N.E.B. to commence operation and start filling the pipe.91 Operations could commence May 1 with a 250,000 barrel a day capacity expected once facilities are completely operational.92

Ottawa established a subsidy for importers of foreign oil used in Canada starting in $1974 . .^{93}$ The subsidy is paid to importers of crude or refined products who are forced to pay prices higher than the Canadian domestic price set by Ottawa.94 The revenue that Ottawa collects from its export tax goes toward the subsidy program. ${ }^{95}$ The export tax, the domestic price for oil, and the subsidy for imported oil are all authorized and administered under the Petroleum Administration Act. ${ }^{96}$ The various provisions of the Act operate in combination to give Canada uniform oil prices.

The Petroleum Administration Act was first introduced as Bill C-18 in April 1974, but died on the order paper when the May 1974 budget was defeated. The Petroleum Administration Act eventually passed the House of Commons on April 30, 1975, with retroactive effect to April 1, 1974. 'The Act is broken down into five major parts. Part I sets out the rules governing the levying, collection, and enforcement of the export tax from April 1, 1974 on. Part II provides a mechanism for setting the price of domestic oil and enforcing that price as the maximum price a producer may charge or a purchaser may pay. Part III deals with natural gas pricing and is beyond the scope of this paper. Part IV sets out the mechanism under which foreign imports of oil receive subsidies and by which the cost of transporting oil or products to fill short term shortages is subsidized. Part V deals with general administration of the Act including information gathering and investigative powers, price review, and reports required to be made to the House of Commons or the Minister of Energy, Mines and Resources.

A uniform domestic oil price for all of Canada is achieved by balancing the following economic factors:97 (1) the cost of foreign oil landed in Montreal or the Maritimes; (2) the estimated cost of foreign oil landed in Chicago; (3) the level of exports to the U.S. of Canadian oil; (4) the Canadian wellhead price; (5) the cost of shipping Canadian oil to domestic markets; (6) the amount of the export tax levied on Canadian oil exported to the U.S. The cost of foreign crude landed in Canada or in

\footnotetext{
ny Id.

Id.

${ }^{91}$ Id.

YII Id.

9. Petroleum Administration Act, S.C. 1975-76, c. 47 at 8. 378.

* Id., Part IV, Division I.

95 McFarland, Don; Legal Dept., Mobil Oil Canada Ltd.; interviews in Calgary, Feb. 5 and 6, 1976.

* Supra, n. 93.

9: Supra, n. 82. Harper, Jim and White, Bill, Transportation Division, Mobil Oil Canada, interviewed in Calgary, February 6, 1976-the overall scheme of the Petroleum Marketing Act as described was pieced together from these interviews plus my study of the Act and other reports in newspapers and journals.
} 
Chicago is beyond the control of the N.E.B. as is the cost of transporting oil from western Canada to eastern Canadian markets. These factors are determined by political and economic forces outside of Canada and in the case of transportation costs by the actual cost of transporting the oil. The volume of oil exported to the U.S. is determined by estimating the current and future domestic supply and demand for Canadian oil and then apportioning some of the excess domestic production capacity to export markets. The Canadian wellhead price for oil is determined by agreement between the producer provinces and the federal government. The price is set in Alberta by the A.P.M.C. on an understanding with Ottawa. ${ }^{98}$ The export tax is set by estimating the cost of Canadian oil landed in Chicago without the tax and subtracting this from the estimated cost of comparable Arabian oil landed in Chicago. The difference is the export tax.99

The Canadian domestic price of oil is the Canadian wellhead price plus the cost of transportation to Canadian markets, the cost of refining is added to give product prices. 100 Using the price of Canadian oil or refined products in the Toronto market as the Canadian domestic price the N.E.B. gives refunds to importers upon application by the importers. ${ }^{101}$ The importer must indicate the quantity and cost of the crude oil or refined product and the N.E.B. will pay him an amount equal to that portion of the cost which exceeds the domestic price for either crude oil or refined product. ${ }^{102}$ The importer is then required to sell his products at prices that are in line with the domestic price in Canada. ${ }^{103}$

Part of the N.E.B.'s job is the making of the complex calculations required to ensure that the amount of revenue from the export tax is sufficient to cover the amount of payments under the subsidy program. ${ }^{104}$ Three factors control the revenue available from the export tax: (1) volume of exports, (2) domestic wellhead price, (3) the world price of oil. The volume of exports is determined by the available reserves in the ground, the developed productive capacity, and the estimated domestic demand for those reserves and productive capacity. ${ }^{105} \mathrm{By}$ examining these factors the N.E.B. estimates the quantity of productive capacity that is surplus to Canada's needs and allocates export quotas and permits based on those calculations. ${ }^{106}$ Currently Canada's production capacity is declining ${ }^{107}$ due to a lack of major new discoveries and the depletion of old fields, while Canada's domestic demand for oil is increasing at a rapid pace. Canada is in a position where her production available for export is being reduced. ${ }^{108} \mathrm{As}$ the level of exports decrease revenue from the export tax will also decrease, unless the level of the export tax is increased. But the export tax cannot be increased unless

98 Supra, n. 21.

99 Supra, n. 82.

100 Id.

101 Supra, n. 93 at $72-77$.

102 Supra, n. 82

${ }^{103}$ The domestic price of oil products at the retail level is controlled by each province via various boards and commissions.

104 Supra, n. 95.

105 Supra, n. 78.

106 Id.

107 Id.

10s Id. Edmonton Journal, March 31, 1976. 
the world price for oil increases. Since the export tax is the difference between the Canadian wellhead price plus transportation to Chicago and world oil transported to Chicago, ${ }^{109}$ any increase in the export tax without an increase in the world price or a decrease in the domestic wellhead price would make Canadian oil uncompetitive in the U.S. market, further reducing the volume of exports taken.110 During part of 1974 and 1975 heavy crude production was shut in because the export tax had been set too high and made heavy crude uneconomical in its U.S. market.111 Increased export taxes without other adjustments either domestically or abroad would only reduce revenue by reducing demand for Canadian oil. Reductions in the domestic price are no answer because that would widen the gap between domestic and foreign prices and thus increase the level of expenditure to support the subsidy. Increases in the price of foreign crudes have the same effect as reducing domestic prices, the level of expenditure required to pay the subsidy would be increased. There is only one option open to the federal government when export volume is reduced, unless the government diverts lower priced Canadian oil to markets currently using imported oil, that is to raise the domestic price. An increase in the domestic price will reduce the amount of expenditure required to meet import subsidy payments at any given world price for oil. By raising the domestic price Ottawa can keep the subsidy program in balance with export tax revenues. The formulae becomes complicated because increasing the domestic price also decreases the export tax and therefore it decreases the export tax revenue. As exports are decreased it will require ever greater price increases to keep tax revenue and subsidy spending in balance until eventually Canada's domestic price will have to meet the world price at which time the subsidy and the export tax will be reduced to zero.

If Canada is to become completely self-sufficient in oil she will have to rely on new and much more expensive sources of oil such as Alberta's tar sands, Arctic oil and oil found under the sea bed.112 Canada's conventional reserves of oil will eventually run out and the N.E.B. predicts that Canada will be forced to import more oil than she can produce by $1982 .{ }^{113}$ As conventional oil supplies dwindle Canadians will be forced to pay much more for their oil since the alternate sources are going to be much more expensive to find, develop and produce than the conventional sources of oil were.114 Also, new supplies will not be available in time to meet the shortfall and imported oil will have to be used.115 Prices will likely become even higher than present world prices for oil produced in the Arctic or from the tar sands. If we are going to become self-sufficient we had better start learning how to conserve our oil and at the same time provide funds for exploration and development work so that new sources will be ready to come on stream when conventional reserves dry up. The best way to achieve both of these objectives is to put the price of oil up to world price levels as fast as

\footnotetext{
109 Supra, n. 82.

110 Id.

iI Oilweek, May 12, 1975 at 7.

112 NEB Report, supra, n. 78.

113 Id. at 6-4.

III Id., and supra, n. 78. at 6 .

115 Id. and supra, n. 78.
} 
possible. If Canadians had to pay world prices for their oil maybe they would start turning their thermostats down and leaving the car at home instead of driving to work. Any savings Canadians can make by reducing their consumption demand will help to prolong the life of our conventional reserves and to give the oil companies more time to find replacement reserves. An increase in prices to world levels would also make more money available to the oil companies to carry out exploration programs and therefore to find and develop new reserves faster. I would recommend that the next price increase at the wellhead, scheduled for July 1976, jump the price to world levels, but an increase of $\$ 2.00$ a barrel would help..$^{116}$

\section{THE A.P.M.C.-HISTORY, FUNCTIONS, SCOPE}

\section{(1) History}

The A.P.M.C., Alberta Petroleum Marketing Commission, operates with the powers and authority granted to it pursuant to the Petroleum Marketing Act; S.A. 1973, c. 96, Parts 1, 2 \& 3 of which were proclaimed effective January 15, 1974.117 The three members of the A.P.M.C. were appointed on January $15,1974 .{ }^{118}$ The Commission's first official act was to issue a Selling Price Bulletin for Crown petroleum effective March 1, 1974. ${ }^{119}$ The bulletin, which reflected prevailing industry prices, consolidated prices across the province for the first time and included previously unpublished prices. ${ }^{120}$ The April 1, 1974 bulletin reflected the increase of the average wellhead price to $\$ 6.50$ per barrel under the first federal-provincial pricing agreement.121

The Commission officially started receiving and selling oil March 1, 1974. In actual fact the Commission was involved in selling oil in name only until December $1,1974 .^{122}$ The industry methods and practices were not disturbed until after studies and reports authorized by the Commission were completed and approved.123 A joint working group of industry and government representatives was formed to study the industry's operations and recommended procedures to be followed under the A.P.M.C.'s control.124 In essence the industry set up a system which was adopted by the Commission and is the basis of the Commission's Responsibilities and Procedures Manual which outlines the duties and responsibilities of the producer, the A.P.M.C. and the purchaser. ${ }^{125}$

Alberta Regulation 304/74, Petroleum Marketing Regulations, was enacted pursuant to sections 19 and 22 of the Petroleum Marketing Act. Pursuant to the authority to give directions in fulfillment of its duties and obligations under the Act granted by section 2 of the regulations the Commission issued directions to the industry on November $29,1974^{126}$

\footnotetext{
116 The new pricing agreement to take effect July 1, 1976 will raise the average price of crude at the wellhead by $\$ 1.50$ to $\$ 9.50$ on July 1, 1976. Edmonton Journal, May 18,1976 .

i1 Supra, n. 3 at 6.

Iin Id.

119 ld. at 7.

12in Id.

121 Id.

122 Id.

${ }^{123}$ Id.

124 Id.

${ }_{125}$ Supra, n. 2.

12" Directions are available from the Commission upon request.
} 
placing the system worked out by the joint working group in effect as at 7:00 a.m. MST on December 1, 1974.

\section{(2) Functions}

The Commission currently has two main functions with respect to the selling of oil.127 The first is calculating the price at which the Commission will take delivery of Crown oil and publishing this price in its monthly pricing bulletin. The second is the receipt and sale of Crown oil. Both these functions will be discussed in more detail in the next section of this paper, under "Practices and Procedures" of the A.P.M.C. In essence the only selling function the Commission performs is the reconciliation of accounts, and the collection and processing of accounting data connected with sales of Crown petroleum. ${ }^{128}$ The industry still arranges the sales and handles the physical delivery of all Crown petroleum to its purchaser, ${ }^{129}$ who in the case of some companies is also the producer. ${ }^{130}$ Companies such as Mobil, Imperial and Gulf Oil often purchase oil produced from their own field from the Commission.

The Commission also receives inquiries from parties interested in locating new refinery or petrochemical industries in Alberta. ${ }^{131}$ The Commission monitors the international petroleum situation, meets with the N.E.B. and other federal and international agencies to discuss prices and marketing and makes reports to the provincial government of related information and recommendations. ${ }^{132}$

The A.P.M.C. maintains offices in Calgary and Edmonton with the head office in Calgary. ${ }^{133}$

\section{(3) Scope}

Section 13 of the Petroleum Marketing Act defines the Commission's basic powers. The section reads: The Commission may:

(a) acquire, sell or exchange petroleum in Alberta;

(b) act as agent or broker in connection with a purchase, sale or exchange of petroleum in Alberta;

(c) construct, purchase, lease or otherwise acquire, operate and dispose of storage facilities in Alberta for petroleum and pipe lines in Alberta for the transmission of petroleum, to and from such storage facilities;

(d) acquire, hold and sell or otherwise alienate any estate or interest in real property in Alberta;

(e) make such banking arrangements as are necessary for the conduct of its business and affairs;

(f) draw, make, accept, endorse, execute and issue promissory notes, bills of exchange and other negotiable and transferable instruments;

(g) do any act incidental to or in connection with the exercise of any of its powers under this or any other Act.

The powers of action granted under section 13 are so broad that virtually no dealing with respect to Crown petroleum within Alberta is beyond the power of the Commission to control, or to undertake itself.

The Commission has used only a small fraction of its potential

127 Supra, n. 2.

12N Supra, n. 21 and n. 95. Id.

129 Id.

130 Supra, n. 95 and n. 82.

i:n Supra, n. 3 at 8.

132 ld.

1:3 Id., 1,000 Bow Valley Sq. Two, 205 - 5th Ave. S.W., P.O. Box 9094, Calgary, Alberta. T2P 2 W4. 
powers to date. Its current exercise of power has not substantially changed the operations of the oil industry as they existed before the Commission came into being. ${ }^{134}$ In the future the Commission plans to play a much more active role in the sale of Alberta Crown petroleum. ${ }^{135}$ The Commission wants to take over the function of supply management and transportation of petroleum currently controlled by the oil companies. ${ }^{136}$ The job would be a difficult one and would require a large staff of trained experienced people.137 The supply and transportation department of an oil company arranges sales or purchases of petroleum and makes sure that deliveries to the refinery operate smoothly so that the specific grades or types of crude that each individual refinery needs are available when they are needed and in the quantities needed. ${ }^{138}$ This is a complex job with hundreds of sources of petroleum, seasonal demands, and varying refinery specifications to juggle. ${ }^{139}$ There are currently at least 60 people in the various oil companies whose job is to ensure that their company receives the oil it needs when and where that oil is needed. ${ }^{140}$ The industry is very much afraid of the A.P.M.C. moving into supply and transport management. They feel that the only people who can properly handle their vital job are the people working for the oil companies who have their companies' interests and their job on the line. The industry fears that the interference of a bureaucrat between the source of supply and the refinery will cause serious problems in an area that requires quick precise action. ${ }^{141}$ The A.P.M.C. argues that they must move into this area in order to ensure that new petrochemical industries moving to Alberta can be guaranteed supplies of feedstock on a priority basis in furtherance of Alberta's policy of encouraging secondary industry to settle in Alberta. ${ }^{142}$ The industry's answer to this is that industry policy has always been to supply upstream facilities first; therefore, Alberta users would be given priority, and that in any event the means of ensuring supply to Alberta plants already exists in the power of the E.R.C.B. to allocate production. ${ }^{143}$

Any move by the A.P.M.C. to guarantee supplies to Alberta customers that prejudices customers in other provinces could spark a second federal/provincial dispute. ${ }^{144}$ If the matter were ever brought before the courts Ottawa would likely win. Alberta's strongest constitutional argument is based on proprietary rights to deal with and dispose of property for the benefit of the provinces. ${ }^{145}$ However, there is a question as to how far this power to dispose of provincial resources will be allowed to encroach upon the federal government's control over

134 Supra, n. 21 and $n .95$ and n. 82. The only change has been the imposition of a middleman who collects and disburses money and accounting data.

135 Supra, n. 2.

${ }^{136}$ Ibid. Supra, n. 95 and n. 82 and n. 97 . Harper, op. cit.; White, op. cit.

137 Id.

135 Id.

139 Supra, n. 82.

$140 \mathrm{Id}$.

14 Id. The industry fears that if the A.P.M.C. were to take over control of the day to day supply operations that the bureaucracy of the A.P.M.C. would not be able to act as quickly to solve the industries' day to day supply problems as is necessary to keep the refinery operating at peak efficiency.

142 Supra, n. 2.

143 Supra, n. 82.

i4 Supra, n. 97.

145 Supra, n. 95 and n. 21 and n. 14. Reed, Vince, of Mclaws \& Co., Barristers \& Solicitors, Calgary, Counsel for · A.P.M.C. Interviewed in Calgary, February 6, 1976. (See the discussion of the Energy Session for more detail.) 
interprovincial and international trade and commerce. ${ }^{146}$ It is clear that the province may conserve its scarce resources and guarantee their use to the producer province first, but it is not clear that this power would permit the province to act to the detriment of the country as a whole by withholding resources from other provinces. ${ }^{147}$ Most of my interviews and readings indicate the federal government would come out on top in a constitutional fight before the courts.

The chances of there ever being an issue put to the courts on the constitutional validity of the Petroleum Marketing Act is remote. Even if a second round of power plays should result from the A.P.M.C.'s proposed actions it would likely be resolved by negotiation and compromise in much the same way as the pricing issue has been resolved.

As the Petroleum Marketing Act currently stands the A.P.M.C. has a great deal of potential power to deal with Alberta's oil resources. The only potential limitation to their scope of action would arise from the federal government moving to counter any action on the part of the province whose effect was detrimental to the overall good of Canada.

\section{PRACTICES AND PROCEDURES OF THE A.P.M.C.}

The A.P.M.C.'s functions include price setting and marketing of crude oil produced from Crown lands. This section of my paper will attempt to summarize the mechanics of how these two functions are performed. If the reader desires more detailed information it is readily available by contacting the A.P.M.C. ${ }^{148}$

\section{(1) Pricing ${ }^{149}$}

Monthly price bulletins are issued by the A.P.M.C. with respect to the price at which Alberta Crown petroleum will be sold at the wellhead or pipeline delivery point within Alberta. ${ }^{150}$ The Commission derives its authority to set the selling price of the Crown's royalty share of oil from section 170.1 of the Mines and Minerals Act, ${ }^{151}$ and section 15 of the Petroleum Marketing Act. ${ }^{152}$ These sections require the producer to

146 Id.

147 Rea, Douglas L., "Constitutional Aspects of the Alberta Petroleum Marketing Act and The Saskatchewan Oi and Gas Conservation, Stabilization and Development Act"; unpublished, prepared for M. J. Sychuk. For Advanced Petroleum Law, U. of A., Faculty of Law, April 18, 1974, p. 20.

148 Supra, n. 133.

149 My analysis of the relevant legislation based on information received from the A.P.M.C. follows.

iso Supra, n. 2.

151 170.1 (1) Every agreement to which this section applies is subject to the condition that the Crown's royalty share of the petroleum recovered pursuant to the agreement shall be delivered to the Alberta Petroleum Marketing Commission incorporated under The Petroleum Marketing Act.

(2) This section applies only to those agreements to which it is made applicable by the regulations under subsection (3).

(3) The Lieutenant-Governor in Council may make regulations declaring this section applicable either

(a) to all agreements granting petroleum and natural gas rights or petroleum rights, or

(b) to agreements granting petroleum and natural gas rights or petroleum rights the locations of which are situated in the part or parts of Alberta specified in the regulations.

(4) The Minister may, with respect to any agreement to which this section applies and in any special case where he considers it warranted by circumstances to do 80 , waive compliance with subsection (1) for any period of time and upon any condisiotns he may prescribe.

152 15. (1) The Commission

(a) shall accept delivery within Alberta of the Crown's royalty share of the petroleum recovered pursuant to an agreement and required to be delivered to it by section 170.1 of The Mines and Minerals Act, and

(b) subject to subsection (2), shall sell within Alberta the Crown's royalty share of petroleum at a price that is in the public interest of Alberta.

(2) Where it accepts delivery of any petroleum pursuanc to subsection (1), clause (a), the Commission may arrange for the storage of that petroleum within Alberta unil such time as it has arranged for the sale of that petroleum at a price that is in the public interest of Alberta or for the utilization of that petroleum within Alberta. 
deliver and the Commission to receive delivery of the Crown's royalty share of petroleum and that the Commission sell the Crown's royalty share at a price that is in the best interests of the province of Alberta. Section 170.2 of the Mines and Minerals Act $^{153}$ requires that the oil recovered from Crown lands be sold through the A.P.M.C. and section 21(1)(a) of the P.M.A. ${ }^{154}$ names the Commission the exclusive agent to sell the lessee's share of petroleum, with the exclusive powers to negotiate and agree to the price at which that petroleum is sold. The Commission as the seller of all oil produced from Crown lands has the power to set the selling price pursuant to sections 15 and 21 of the Petroleum Marketing Act.

The pricing bulletin ${ }^{155}$ is in four parts. The first part lists the prices for oil delivered from various fields and locations into the lines of a pipeline company's gathering system right at the field. The second part lists prices for deliveries from particular fields or areas to a pipeline terminal by truck, the price is listed as upon delivery to the terminal from a particular location or field. The third part lists prices paid for heavy crudes delivered into a pipeline gathering system at the field or area listed. The fourth part lists the price of heavy crude upon delivery to a particular pipeline terminal from a particular field or location by truck. All quantities delivered are received and computed in accordance with existing regulations of the pipeline company, corrected to $60^{\circ} \mathrm{F}$ with full deductions for bottom sludge and water.

Prices listed in the February 1976 bulletin are based on the July 1, 1975 price agreement between Alberta and Ottawa which establishes the price of crude delivered to the Edmonton terminal of the Interprovincial Pipeline Company at $\$ 8.31$ per barrel with A.P.I. gravity of $42^{\circ}$ or higher and sulfur content by weight of $.5 \%$ or less. ${ }^{156}$ Prices for heavy crude are

1s 170.2 (1) Every agreement to which this section applies is subject to the condition that the petroleum recovered pursuant to the agreement, other than the Crown's royalty share thereof, shall be sold through the Alberta Petroleum Marketing Commission incorporated under The Petroleum Marketing Act.

(2) This section applies only to those agreements to which it is made applicable by the regulations under subsection (3).

(3) The Lieutenant-Governor in Council may make regulations declaring this section applicable either

(a) to all agreements granting petroleum and natural gas rights or petroleum rights, or

(b) to agreements granting petroleum and natural gas rights or petroleum rights the locations of which are situated in the part or parts of Alberta specified in the regulations.

(4) This section applies to an agreement notwithstanding any contract or arrangement made before or after the commencement of this section and relating to the sale or other disposition of the petroleum recovered from the location of the agreement and no party to any such contract or arrangement has a cause of action against any other party thereto by reason of the effect of the operation of this section upon that contract or arrangement.

(5) The Minister may, with respect to any agreement to which this section applies and in any special case where he considers it warranted by circumstances to do 80 , waive compliance with subsection (1) for any period of time and upon any conditions he may prescribe.

15s 21. (1) The Commission

(a) is the exclusive agent to sell the lessee's share of petroleum on behalf of the owner thereof, with the exclusive power to negotiate and agree to the price at which that petroleum is sold.

(b) shall sell within Alberta the lessee's share of petroleum at the highest price that it may reasonably negotiate having regard to market conditions prevailing at the time of the sale;

(c) shall, upon the sale of any of the lessee's share of petroleum, pay to the owners thercof the proceeds of the sale, without any deductions whatever;

(d) shall make payment under clause (c) within 60 days after the sale of the petroleum;

(e) shall, in carrying out its responsibilities under clauses (a) to (d), diligently endeavor to encourage and promote the orderly and equitable marketing of the lessee's share of petroleum;

(f) shall not in selling petroleum under this section discriminate as between owners or as between petroleum from different pools or other sources, except as may be necessary to effect the orderly and equitable marketing thereof.

(2) The lessee's share of petroleum shall not, prior to its sale by the Commission, be exchanged for any other petroleum.

155 The Bulletin for February 1976 is used throughout my analysis of the A.P.M.C.'s price setting function.

1ss "Selling Price Bulletin for Crown Petroleum"; effective 7:00 a.m. M.S.T. on the First Day of February, 1976; Alberta Petroleum Marketing Commission; at 1, 10 
based on their commodity value in relationship to light or medium crudes and are calculated with relation to the terminal or pipeline into which they are delivered. ${ }^{157}$ The $\$ 8.31$ Edmonton terminal price results in an average wellhead price of $\$ 8.00$ a barrel for oil produced in Alberta once transportation and quality deductions are calculated.

The price of oil from a specific location or field as listed in the bulletin is calculated by deducting the gathering and transportation charges and charges for A.P.I. gravity and sulfur content from the $\$ 8.31$ standard price at the Edmonton terminal. For example, if a well near Ponoka produced oil with an A.P.I. gravity rating of $38^{\circ}$ and sulfur content of $.59 \%$ by weight, and was delivered into a gathering line of a pipeline company at the wellhead, the price of that oil would be determined as follows:158 (1) the cost of gathering the oil would be deducted from the $\$ 8.31$, say, $\$ .05$, (2) the cost of transporting the oil to Edmonton would be deducted, say $\$ .10$, (3) the penalty for A.P.I. gravity would be deducted at $\$ .03$ per every $1^{\circ}$ under $42^{\circ},(42-38) \times .03=\$ .12$, (4) the penalty for sulfur content would be deducted at the rate of $\$ .02$ for every $0.1^{\circ}$ over $.49 \%$ of sulfur by weight $(.59 \%-.49 \%)=.1 \%,(.1 \div .1) \times .02$ $=\$ .02$. The price calculated back to the wellhead would be $\$ 8.31-.05-$ $.10-.12-.02=\$ 8.02$ per barrel. The price of a barrel of oil delivered into a pipeline gathering system from a specific location in Alberta during February 1976 is easily determined by referring to "Selling Price Bulletin No. 02-76", 159 the bulletin for February, 1976 for oil delivered to a pipeline gathering system. Likewise the price of heavy crude delivered to the pipeline gathering system from a specific location during February 1976 is easily determined by reference to "Selling Price Bulletin H02$76 " .160$

In the case of oil which is trucked to the pipeline terminal the Commission calculates the price at the terminal of oil from a specific field by deducting transportation costs from the gathering terminal to the Edmonton terminal and A.P.I. gravity and sulfur penalties from the $\$ 8.31$ standard price. Trucking allowances are available to the purchaser upon request and submission and approval of the trucking charges negotiated between the producer and the purchaser of the oil. ${ }^{161}$ The A.P.M.C. takes delivery of the oil and resells it to the purchaser at the wellhead but the purchase price is calculated at the pipeline terminal in the cases where trucking is required; therefore, the A.P.M.C. allows the purchaser to deduct the cost of trucking the oil to the terminal from the price payable to the Commission for the purchase. ${ }^{162}$ For example, if the relevant terminal price was listed in the bulletin as $\$ 8.00$ a barrel and the approved trucking allowance for trucking the oil to the pipeline terminal was $\$ .50$ the purchaser would only pay the Commission $\$ 7.50$ per barrel for the oil received. The prices of oil subject to trucking for

15: Since heavy crudes do not flow through the source distribution network as light and medium crudes their price calculation at the wellhead is based on the system into which they are delivered; but the calculation is made in accordance with the Edmonton Terminal Price agreed on between the federal and provincial governments, in this case, $\$ 8.31$ per barrel; $I d$. at 23 and at 25 .

15N The illustration used is hypothetical, it does not represent actual values or prices in the Ponoka field.

isy Supra, n. 156 at 1.

160 Id. at 23.

161 A.P.M.C.; "Reporting and Proceeds Distribution for Crown Petroleum; Responsibilities and Procedures. Effective December 1, 1974, Revised Jan. 1, 1976; at 85-100-Appendix B. "Transportation Allowances."

162 lbid. at 86 and 87 . 
light and medium, and heavy oils are listed under Pricing Bulletin T0276, and HT02-76 respectively for the month of February $1976 . .^{163}$

Because Crown oil comprises approximately $80 \%$ of all oil produced in Alberta the prices set for Crown oil are usually also the prices at which freehold oil is sold.

\section{(2) Marketing}

Alberta has exercised its right to take its royalty share of petroleum in kind since March 1, 1974 when Alberta Regulation 15/74 pursuant to sections 170.1 and 170.2 of the Mines and Minerals Act declared those sections applicable to all agreements granting petroleum and natural gas rights or petroleum rights as of that date. Section 170.2 commands that the lessee's share of Crown petroleum be sold through the A.P.M.C. while section 170.1 demands that the Crown's royalty share be delivered to the A.P.M.C. The Commission is the agent of the Crown in the right of Alberta under section 7 of the Petroleum Marketing Act for the purpose of receiving and selling the Crown's share of petroleum under section 15 of the Act. The Commission acts as exclusive agent for the sale of the lessee's share of petroleum under the terms of section 21 of the Petroleum Marketing Act. The Commission has the exclusive right under these provisions to receive and sell all petroleum produced pursuant to Crown agreements. Section 170.2(4) of the Mines and Minerals Act gives the Commission the power to affect or alter any sales for petroleum made before or after the section came into force without giving rise to any cause of action. Section 21(2) of the Petroleum Marketing Act prohibits the exchange of the lessee's share of petroleum for any other petroleum prior to its sale by the Commission, Alberta Regulation 304/74 section 4 gives the Commission the power to direct that the lessee's share of petroleum be sold to the Commission in any case. The totality of these sections gives the Commission complete control over the lessee's share of Crown petroleum as well as over the Crown's royalty share of petroleum.

By law the A.P.M.C. is the exclusive selling agent for all oil produced pursuant to Alberta Crown leases, and all sales are theoretically made through the A.P.M.C. In fact all sales and deliveries of Crown petroleum are arranged between the field operator and the purchaser of the oil.164 The Commission sets the terms of the contract with respect to price, payment, and accounting data required from both the producer and the purchaser of Crown oil. ${ }^{165}$

The mechanics of the A.P.M.C.'s role together with the report forms and requirements to complete a sale of Crown oil are set out in detail in the A.P.M.C. manual titled "Reporting and Proceeds Distribution for Crown Petroleum, Responsibilities and Procedures", first put into effect December 1, 1974 and revised effective January 1, 1976.

The mechanics of the transaction are as follows: ${ }^{166}$

(1) Approved operators report total petroleum deliveries and identify Crown petroleum deliveries to A.P.M.C. and approved Alberta purchasers before the 15 th day of the month following the month in

\footnotetext{
163 Supra, n. 156 at 10 and at 25.

164 Supra, n. 128.

163 Id.

166 Supra, n. 161 at 1 and at 2.
} 
which deliveries occurred, report form P.M.C.-1 is used. Operators are also to summarize Crown royalty share of petroleum, production, inventory, adjustments and deliveries, and the Crown lessee share of deliveries using form P.M.C.-2(1). Crown royalty petroleum retained in inventory or subject to adjustment is to be reported in detail on form P.M.C.-2(2). Forms P.M.C.-2(1) and P.M.C.-2(2) are due on the 18th of the month following the month of production and deliveries.

(2) The A.P.M.C. upon receipt of form P.M.C.-1 will invoice approved Alberta purchasers on the 20th day of the month following delivery of Crown petroleum. The purchasers are to have cheques dated and payable as on the 25th day of the month for receipts of the previous month. These are to be delivered on or before the 24th day of the month.

(3) The A.P.M.C. will remit the lessee's share of the proceeds to approved operators, subject to court orders, for their distribution upon receipt of Operator P.M.C.-1 and P.M.C.-2 forms by the dates specified. The A.P.M.C. will also make remittances to the Provincial Treasurer of the Crown's royalty share. These remittances occur on the 25th day of the month following the month in which deliveries occurred and follow the traditional settlement practices in the industry for sales earlier than under the old practice.

(4) All purchaser and operator account reconciliations, adjustments and lessees' share of adjustments will be calculated and prepared for remittance on the 25th day of the second month following the month in which deliveries were made. This ensures that all payments required to be made by the Commission will be made prior to the 60 day time limit imposed by section 21(1)(d) of the Petroleum Marketing Act. In general, adjustment of errors of price or volume will be included in the A.P.M.C. invoice to the purchaser.

(5) Crown royalty adjustments will be made only between the operator and the A.P.M.C. The A.P.M.C. receives verified royalty barrel calculations from the Department of Energy and Natural Resources and after verifying the price will include adjustments to the Crown royalty share in remittance to the operator and the Provincial Treasurer on the 25 th of the second month following the month in which deliveries occurred.

All dates are subject to business transaction days. If any date falls on a non-banking day or holiday the nearest business day prior to that date supercedes it, unless otherwise specified in an official A.P.M.C. release to industry.

It is important to note that when petroleum is produced and only part of it is sold in that month the Commission deems that the Crown's royalty barrels are the first barrels sold. ${ }^{167}$ For example, if a well produces 100 barrels of crude, 40 are royalty barrels, and only 40 barrels of those 100 barrels produced are sold immediately the 40 barrels sold are the royalty barrels and the proceeds of sale are paid to the Provincial Treasurer. The lessee/operator receives nothing until part or all of the remaining 60 barrels are delivered and sold.

(3) Force and Effect-Responsibilities and Procedures

The Commission views its Responsibilities and Procedures Manual as 
carrying the force and effect of law. ${ }^{168}$ The source of its belief is that the manual forms part of or is authorized by the Commission's direction to the oil industry in Alberta dated November 29, 1974.169 There are two possible grounds for holding that the manual does not carry the force of law: (1) the granting of the power to make directions is ultra vires the power of the Lieutenant-Governor in Council to grant this power must be granted by the Legislature; ${ }^{170}$ (2) the directions themselves do not incorporate or authorize the incorporation of the Responsibilities and Procedures Manual. ${ }^{171}$

The Petroleum Marketing Act sections 19 and 22 authorize the Lieutenant-Governor in Council to make regulations for the administration of parts II and III of the Act respectively. Pursuant to these sections Alberta Regulation 304/74, Petroleum Marketing Regulations, was enacted. Section 2 of the regulation authorizes the Alberta Petroleum Marketing Commission to make such directions as it considers necessary with respect to petroleum sold or to be sold by the Commission, and persons to whom such directions are given are required to comply with those directions. The Commission argues that this gives its directions the force of law and that is correct unless and until the power to make directions is challenged and struck-down in a court of law. ${ }^{172}$ One possible ground for attacking the directions is that the LieutenantGovernor in Council does not have the power to sub-delegate delegated legislative powers. ${ }^{173}$ These directions could be viewed as legislative in nature and since there is no authority or power to act legislatively conferred upon the Commission by the Legislature of Alberta the power to make directions is ultra vires the powers of the Commission. This argument is dependent upon the making of directions being legislative in nature. In any event the directions carry the weight of law until they are struck down and it is unlikely they will be contested. No oilman would want to start a fight with the Commission over such a small point. Besides the Commission could have the matter cleared up very quickly by having the Legislature grant them the power to enact directions, by having the directions that they wish to implement made part of the regulations or by having new regulations enacted that incorporate the responsibilities and procedures as set out in the manual.

There is also a question as to whether the responsibilities and procedures set out in the manual are properly incorporated into or authorized by the directions in order to give them the force and effect of law. In any event this is a minor point easily corrected by issuance of further and better directions which expressly incorporate the responsibilities and practices manual provisions. The oil companies are content to accept the procedures as set out so the whole question will likely remain moot.

\footnotetext{
IGik Id.

169 Directions by the Alberta Petroleum Marketing Commission to Lessees, Operators, Purchasers, and Pipeline Operators as to Petroleum Produced from Alberta Crown Lands After 7:00 a.m. M.S.T. on the First Day of December, 1974.

170 Rutter, M. F., Lecture Outlines on Administrative Law, Faculty of Law, the University of Alberta, January 1, 1976; at 5.

17 Biggs, In-house council, for A.P.M.C. Interviewed at the Commission supra. n. 2.

172. Supra, n. 170.

173 Id.
} 


\section{THE PETROLEUM ADMINISTRATION ACT ${ }^{174}$}

In this paper I have not included a section on the detailed operation of the subsidies under Part IV of the Petroleum Administration Act even though these subsidies interrelate with the domestic price of oil and the export tax since the main thrust of my paper is the pricing of Alberta's oil and not pricing of oil in Canada Generally. The subsidy and its interrelationship with the price of Alberta's oil is discussed in the first section of this paper under "Background" information.

\section{(1) Edmonton Terminal Price}

The Edmonton terminal price is the price a barrel of crude oil of $42^{\circ}$ A.P.I. gravity and less than $.49 \%$ sulfur content by weight when it is delivered to the Edmonton terminal of the Interprovincial Pipe Line Company. ${ }^{175}$ This price is set by an agreement between the government of Canada and the Alberta government pursuant to section 22 of the Petroleum Administration Act. The Edmonton terminal price has the force and effect of law when it is incorporated into reciprocal orders in council of the Alberta and Canadian governments pursuant to section 22(2) of the Petroleum Administration Act. ${ }^{176}$ The price agreed to by the two levels of government may be established as a maximum price for oil produced, extracted or recovered in the province making an agreement with Ottawa under the provisions of section 23 of the Act. ${ }^{177}$ However, the agreed price has never been formalized under either s. 22 or s. $23 .{ }^{178}$

The Edmonton terminal price forms the basis for calculating wellhead prices in Alberta (as discussed earlier), for calculating the price at which Alberta's oil will be sold in Canadian markets, and for determining the export tax and the price of Alberta oil will be sold at in the U.S. market. ${ }^{179}$

The price of Alberta oil in Toronto is calculated by adding the cost of transportation to Toronto to the wellhead price plus the cost of gathering and transporting the oil to the Edmonton terminal. ${ }^{180}$

The price of a barrel of Alberta oil in the U.S. market is calculated by adding: (1) the cost of gathering and transporting the oil to the U.S. market; (2) the export tax applicable to that type or kind of oil for the month when delivery is made; (3) the U.S. import charge in oil, to the applicable Alberta wellhead price. ${ }^{181}$

The Edmonton terminal price is set at an arbitrary level by agreement between the Canadian and Alberta governments taking into account political and economic factors. ${ }^{182}$

(2) The Export Tax ${ }^{183}$

Part I, section 7, of the Petroleum Administration Act authorizes the

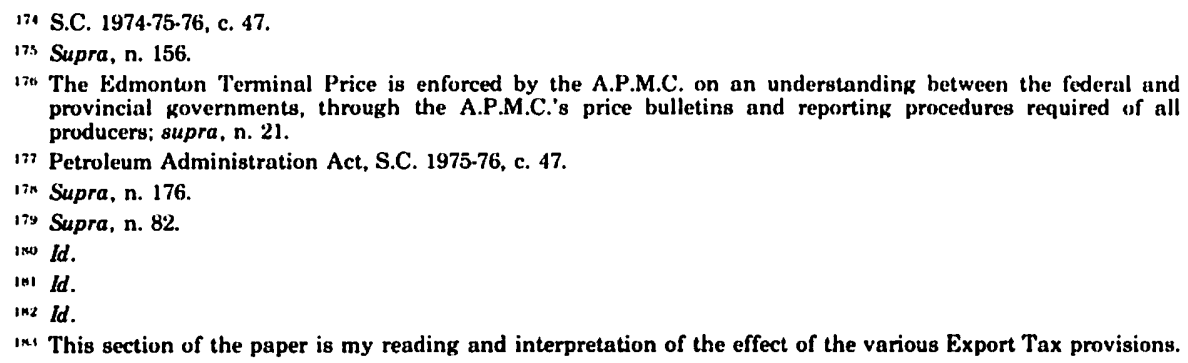


imposition of export charges on all oil exported from Canada as prescribed by Order-in-Council for each month and not exceeding $\$ 8.00$ a barrel. The tariff ${ }^{184}$ prescribed may distinguish between various kinds and qualities of oil and between various destinations, as provided in subsection $7(2)$ of the Act. This is the provision that allows a $\$ .50$ a barrel reduction in the export tax applied to heavy crudes to make them competitive with medium and light crudes. By subsection $7(3)$ the tariff will continue in force in subsequent months if no new tariff is set by Order-in-Council pursuant to subsection 7(1) of the Act.

The export tax now in effect is a more sophisticated animal than the original blanket charge of $\$ .40$ a barrel on all oil that was put into effect in October 1, 1974. ${ }^{185}$ The N.E.B. can now fine tune the tariff to prevent export customers from switching from heavy crude to light and medium crudes as happened in 1974 and 1975 and thus causing the whole oil industry in Saskatchewan to stop production due to lack of demand for its heavy crude oils. ${ }^{186}$ The N.E.B. may also prescribe export charges on bunker fuel and jet fuel used by ships and planes on international voyages or flights. Section 4(1), the definitions section, includes fuels used as bunker or aircraft fuel outside Canada by such persons in such circumstances as may be prescribed by the regulations in the definition of exports. ${ }^{187}$ The purposes of including this in the definition is to allow an export tax to be levied on fuel that is taken on in Canada for an international trip that is greatly in excess of the fuel requirement to get to the next normal fueling stop, thus preventing ships and planes from taking advantage of the protected Canadian domestic price for oil by loading enough fuel for the round trip rather than refueling in a jurisdiction where oil prices are higher than in Canada.

The National Energy Board by section 9 of the Act must promptly report any change in its determination of what a just and reasonable price for exports is for any month in order that new tariffs may be set for the month in which the change is to take effect. The N.E.B. examines and monitors the world price situation, compares the price of foreign oil landed in Chicago to the price of Canadian oil landed in Chicago and recommends new tariffs of export charges for Canadian oil whenever necessary ${ }^{188}$ to ensure that Canadian exports remain competitive while still extracting the maximum revenue from the export tax.

The Governor in Council may by order pursuant to section 12 exempt an exportation of oil from a charge imposed or reduce any charge imposed in respect of any month under section 7(1). This exemption may be conditionally or unconditionally, retroactively or prospectively granted either generally or in respect of a single transaction. Section 11 charges the National Energy Board with the duty to administer and enforce Part I of the Act and to collect charges payable under Part I.

Section 13 requires persons required to pay export charges to file returns of exported oil made in each preceding month together with all

ist The current tariffs of charges are in: "Tariff of Charges for Exported Oil Other than Oil Products Order". SOR 75-582, Canada Gazette 22/10/75, 2755 n \& "Tariff of Charges for Exported Oil Products Order" SOR/75-583, Canada Gazette 22/10/75, $2759 n$.

is5 Bill C245; Oil Export Tax Act, Passed by the Parliament of Canada, January 7, 1974. Effective from Oct. 1, 1973 to April 1, 1974; S.C. 1973-74, c. 53.

108 Supra, n. 63

187 "Tariff of Charges for Exported Oil Products". Supra, n. 184.

16s Oilweek, May 12, 1975, at 7. (See background discussion.) 
charges payable by the end of each month. Subsection $13(3)$ provides a $1 \%$ per month penalty for late payment of charges due and subsection 13(4) provides for extensions of time before penalties are assessed when the Board has specified a later date for payment on filing of returns in writing.

Section 15 deals with deductions or refunds when overpayments or payments in error are made. Refunds are available upon application for moneys paid as charges under a mistake of law or fact as long as application for the refund is made within two years of the time the refund or deduction first became payable or the time overpayment was made.

Section 16 requires persons required to pay charges under Part I to keep records and books of account until written permission for their disposal is obtained form the Board, and to make those books and records available to officers of the Board for inspection when requested to do so.

Section 17 provides an appeal to the Tariff Board constituted under the Tariff Board Act where disputes arise as to whether a charge is payable or to the amount payable on the exportation of any oil. Sections 59 and 60 of the Excise Tax Act apply mutatis mutandis to Part I of the Act. These sections set out the procedure for appeals to the Tariff Board and then to the Federal and Supreme Courts of Canada.

\section{(3) Additional Price Restraints}

Part II, Division II, section 36, of the Petroleum Administration Act establishes a mechanism by which the federal government may unilaterally set prices for oil within a province which sells a significant portion of its production outside of the province in the event that no pricing agreement is reached between the province and the federal government pursuant to section 22 of the Act. It is extremely unlikely that this additional price restraint will ever be needed since the economic factors at work in the Canadian domestic oil situation are driving the price of oil toward world levels ${ }^{189}$ thus the disagreement over pricing which originally gave rise to both Alberta's Petroleum Marketing Act and the federal government's Petroleum Administration Act is no longer the contentious issue it once was. ${ }^{190}$

(4) Enforcement of the Petroleum Administration Act

(a) Part I (Export Taxes)

Section 14 of the Act makes export charges and penalties on oil as provided for in the Act a debt due to Her. Majesty and recoverable in any court of competent jurisdiction. This gives the N.E.B. the power to sue any delinquent exporter in a civil action for recovery of tax and penalties. An exporter who is liable may be a licensed exporter or a person actually exporting oil subject to tax where no licensed exporter is involved under the provisions of section 10 of the Act. Section 14(2) provides that amounts recoverable under Part $I$ of the Petroleum Administration Act may be recovered in the same manner as any amount payable under the Excise Tax Act and for such purpose section 52 of the Excise Tax Act applies mutatis mutandis. References to the

169 Discussed under "Background" Section I of this paper.

190 Supra, n. 145. 
Minister or Deputy Minister are to be construed as applying to the Chairman of the Board or Secretary of the Board of the National Energy Board as the case may require. Section 52 of the Excise Tax Act as applied to the Petroleum Administration Act provides in subsection (2) that penalties for violation of the Act may be sued for and recovered: (a) in the Federal Court of Canada, or in any other court of competent jurisdiction; (b) by way of summary conviction under the provisions of the Criminal Code. Subsections (6) and (7) as applied, provide for collections of debts under the export tax provisions from third parties who become indebted to or are about to become indebted to licensed exporters of oil. The National Energy Board is empowered under the provisions of 8.19 and the incorporated provisions of $\mathrm{s} .52$ of the Excise Tax Act to sue both the exporter and third parties who owe the exporter a debt, to the amount of that debt, in the Federal Court or in provincial courts of competent jurisdiction for recovery of export charges and penalties assessed under the Act. Subsection (1) of section 52 provides that all rights of Her Majesty will be enforced, with full costs of suit, as a debt due or a right enforceable by Her Majesty. Subsection (3) of section 52 provides that every penalty imposed by this Act, applied to P.M.A., when no recovery procedure is provided may be sued for, prosecuted, and recovered with costs, then goes on to delineate who may sue in various parts of the Excise Act. In both instances the costs of bringing the action are awarded by statute to the Crown representative bringing the action for recovery. Thus, the delinquent not only faces suit for arrears and penalties but also for the costs of the action.

Section $52(2)(b)$ as applied, provides a criminal sanction conviction under the Criminal Code against an exporter who violates the export tax rules as provided in the Petroleum Administration Act. This would include breach of information requirements as well as failure to pay charges. Under section 722 of the Criminal Code as offender would be liable to fines on summary conviction of up to $\$ 500$ or 6 months in jail or to both. Where imposition of fines or making of an order for payment of money is authorized by law, but the law does not provide that imprisonment may be imposed in default of payment of the fine or compliance with the order, the court may order that in default of payment the defendant may be imprisoned for up to six months. Thus, apart from civil liability to Her Majesty the exporter faces criminal sanctions for breach of the provisions of Part I of the Petroleum Administration Act.

\section{(b) Part II (Domestic Oil Pricing)}

Division I, the part dealing with pricing agreements between the producer provinces and the federal government creates an offence under section 28 of the Act for a person who (a) knowingly makes any false entry or statement in any record, book of account or other documents required by this Division or any regulation thereunder, or (b) knowingly destroys, mutilates or falsifies any record, book of account or other document required by this Division or any regulation thereunder. An offender under this section is liable on summary conviction to fines not exceeding $\$ 10,000$ or to imprisonment not exceeding one year or to both.

Section 29(1) creates an offence for every person who contravenes any of the provisions of sections 24 to 27 and is liable on (a) summary conviction to a fine not exceeding $\$ 20,000$ or to imprisonment for a term not exceeding six months or to both, or (b) on conviction upon 
indictment, to imprisonment for a term not exceeding two years. Section 29(2) provides that an officer of a corporation guilty of offences who directed, authorized, or assented to, or acquiesced in or participated in the commission of the offence is liable on conviction to the punishment provided for the offence whether or not the corporation has been prosecuted or convicted. Section 29(2) is applied to offences "under this Division" which includes section 28 offences. Thus, the Crown may prosecute and punish both the corporation and the individuals in the corporation and make them liable to very heavy penalties especially since section 31 makes offences committed on more than one day to be separate offences for each day the offence is committed or continues. The various requirements, the breach of which is an offence under section 29 , are as follows: (1) selling or purchasing crude oil for consumption outside its province of production at a price greater than the price prescribed under section 23, (2) transporting crude outside of its province of production without documentary proof that the price paid was in line with the section 23 prescribed price, (3) failure of companies who transport crude oil outside of its province of production to keep records, as required by regulation, of the price at which any crude oil was purchased or sold in the course of a transaction, (4) failure of purchaser to keep records, as required by regulation, of the price at which crude oil acquired for use outside of its province of production was acquired.

The combined effect of the offences under sections 28 and 29 is that records of prices must be kept, and selling or buying at a price greater than the prescribed price set out pursuant to the federal-provincial agreement will result in an offence with very heavy penalties for both the corporation and the officers of the corporation. Also, attempts to falsify or destroy records that might show an offence under section 29 will result in an offence with weighty penalties for both the company and its officers. It is, however, very unlikely that these enforcement provisions will be necessary with relation to oil produced in Alberta since the A.P.M.C. controls the price very effectively. Some problem might arise with the sale of freehold oil but this is unlikely due to economic pressures on price exerted by the A.P.M.C. The oil companies are not likely to risk their public stature for a small temporary gain.

Division II, Additional Price Restraint, incorporates most of the enforcement provisions found in Division I under its section 45. This part will only come into effect if no federal-provincial price agreement is reached. I will not discuss its enforcement further since it is unlikely that this division will ever come into force.

\section{(c) Part V (General)}

The combined effects of sections 89 and 90 of the Act are that the Minister of Energy, Mines and Resources may authorize investigators to enter upon and search premises that they suspect may contain evidence of a contravention of the provisions of the Act, and to carry away documents, books, and records that may contain such evidence in order that these might be examined, and copied, or photographed. Upon production of credentials specified in $\mathbf{8} .90$ the investigator has a right to enter any premises in pursuance of an investigation; if he is refused entrance he may apply for a court order directing a peace officer to take such steps as the judge deems necessary to obtain access to the premises or the desired materials. 
The investigators authorized under the Petroleum Administration Act are given broad powers of entry and search. By merely presenting their credentials they have a right to enter a premises and to look at or remove documents.

Under section 89(1) the Minister may require information returns of corporations or their officers. The information requested and the time for compliance may also require the information be given under oath.

\section{APPENDIX A: ALBERTA'S ROYALTY AND MINERAL TAX MEASURES}

In 1972 Premier Lougheed introduced new royalty and taxation provisions relating to petroleum and natural gas interests granted by Crown leases. These new provisions were contained in the Mineral Taxation Act 1972, S.A. 1972, c. 67, and in the Crude Oil Royalty Regulations Alta. Reg. 377/72. The new royalty scheme necessitated the repeal of section 143 of the Mines and Minerals Act, R.S.A. 1970, c. 238, by the provisions of the Mines and Minerals Amendment Act, 1972, S.A. 1972, c. 68, s. 3.

Section 143 of the Mines and Minerals Act read as follows:

(1) The maximum royalty payable on the petroleum and natural gas during the initial 10 years of a lease granted pursuant to this part shall not exceed one-sixth of the production obtained from the location.

The new Crude Oil Royalty Regulations would exceed the one-sixth maximum in section 143 if the lessee chose to amend his lease pursuant to section 7 of the regulations, therefore in order to allow amendments to existing leases still subject to the one-sixth maximum royalty provisions section 143 had to be repealed. Section 7 of the regulations provided that the lessee could exempt himself from tax on his minerals in situ under the Mineral Taxation Act, 1972 for five years from January 1, 1973 if they elected to amend their leases pursuant to 7(1) of the regulations before July 31,1973 . The incentive was offered in order to encourage amendments to as many leases as possible since the 1972 Crude Oil Royalty Regulations only applied to leases that did not contain maximum royalty provisions or where the term of the maximum royalty provision had expired. Leases still subject to the maximum royalty clause were subject to the calculations in A.R. 80/62 which was left in force and amended by section 11 of A.R. 377/72 only "to the extent necessary to permit the application of these regulations." The new royalty calculated in accordance with schedule $C$ of the Crude Oil Royalty Regulations reached its effective maximum rate of about $22 \%$ at 4,000 barrels of production per month. Since this was a higher rate than the old one-sixth, 16.6\%, maximum under the lease and since it was the lessee's option whether or not to amend the lease many leases remained unamended after the July 31,1973 deadline. These unamended leases made it necessary for the Alberta government to add section 142.1 to the Mines and Minerals Act in its 1973 revisions of the Act. Section 142.1 declares all maximum royalty provisions to be void thus clearing the way for a new royalty scheme with universal application to all Crown leases, and no limitations on its maximum effective rate. Section 142.1 states the following:

Any provision contained in a lease of petroleum and natural gas rights, natural gas rights or petroleum rights granted by the Minister before the commencement of this section and stating

(a) that the maximum royalty on the petroleum during the first term of the lease shall not exceed one-sixth of the gross recovery from the lands described in the lease, or 
(b) that the maximum royalty payable on the petroleum and natural gas during the initial ten-year term of the lease shall not exceed one-sixth of the production obtained from the location, or

(c) that the maximum royalty payable on natural gas during the first term of the lease shall not exceed one-sixth of the production from the location, or

(d) that the maximum royalty payable on petroleum during the first term of the lease shall not exceed one-sixth of the production obtained from the location,

and any provision to a like effect contained in such a lease is void.

This cleared the way for Premier Lougheed to introduce his new Petroleum Royalty Regulations putting them into effect on April 1, 1974 at the same time that the price of crude oil was being raised under a federalprovincial agreement. The Petroleum Royalty Regulations, A.R. 93/74, rescinded and replaced the Crude Oil Royalty Regulations. Section 1 of the Petroleum Royalty Regulations states that the royalty calculation for each month based on production from each well for that month shall be (a) in accordance with schedule $A$ (the wording in schedule $A$ is identical to that of schedule C of the old Crude Oil Royalty Regulations), or (b) where section 2 applies in accordance with section 2 . Section $2(2)$ declares that schedule B, to which section 2(1) and (3) apply, is the appropriate royalty calculation when the par price is greater than the delect price for the month. The par price and the select price are both set by the Lieutenant-Governor in Council under A.R. 94/74 which took effect April 1, 1974. Since April 1, 1974, when the regulations were first in force, the par price has always exceeded the select price. The procedure in schedule $B$ has been the appropriate royalty calculation since the Petroleum Royalty Regulations came into force.

The Royal Calculation in schedule $B$ follows the following formula:

$$
\mathbf{R}=\mathbf{S}+\mathbf{K S}(\mathbf{A}-\mathrm{B})
$$

A

$R=$ the royalty payable, in barrels.

$\mathrm{S}=$ the number of barrels determined in accordance with the table in schedule $\mathrm{B}$. (The operative wording in this table is identical to the wording in schedule A of the 1974 regulations and to the wording in schedule $C$ of the 1972 regulations.)

* $\mathrm{K}$ = the royalty factor for the month that is applicable to the crude oil from the well. (Either new oil or other than new oil as defined in 8.2 of the regulations.)

${ }^{*} A=$ the par price of crude for the month.

* $B$ = the select price of crude for the month.

*the K, A, \& B values are set out in A.R. 94/74 as amended by A.R. 326/74, filed December 18, 1974, and A.R. 207/75 filed July 23, 1975.

The table to schedule $B$ reads as follows:

"Barrel" means 34.9723 gallons.

Monthly Portion of Crown Royalty Payable for the Month in Barrels

0 to 1200 The number of barrels determined by dividing the barrels produced by 120 and adding 5 to the quotient, then multiplying by the barrels produced and dividing by 100 .

1200 and over 180 barrels plus one-fourth of the number of barrels produced in excess of 1200 barrels.

The royalty equation can be broken down into two parts, $S$ and $\mathrm{KS}$ (A-B). S represents the royalty payable under the regulations negoA

tiated in 1972. S as a percentage of production increases directly with output up to the 1200 barrel level after which the second calculation is used. This calculation results in an S figure which approaches $25 \%$ of production as the level of production continues to rise but never quite reaches $25 \%$. For example at the 32,000 barrel level of output the royalty would be $24.6 \%$ while 
at the 4,000 barrel output the royalty is $22 \%$ and at 2,000 barrels output the royalty is $19 \%$. Therefore, the maximum practical $S$ figure, and 1972 royalty is about $22 \%$ of production since 4,000 barrels production per month is about the maximum output from any one well in Alberta.

The second part of the equation KS (A-B) takes into account the price A

increases for oil at the wellhead since 1974 and assesses a royalty which takes about $60 \%$ of the price increase away from the producer on oil other than new oil. The royalty on 4,000 barrels of oil other than new oil produced from a well during a one-month period from April 1, 1974 to December 31, 1974 was 1,556 barrels or $38.9 \%$ of production. The royalty on new oil during that period was 1,075 barrels or $26.9 \%$ on 4,000 barrels production. In December, 1974 in response to the Federal Budget, Alberta raised the select price in the royalty calculation for the month of January, 1975 and subsequent months. This gave the producers some relief by reducing the royalty to 1,406 barrels or $35.2 \%$ on 4,000 barrels production. Then when the wellhead price was raised by federal-provincial agreement after July 1, 1975 to $\$ 8.00$ per barrel, the par price and the royalty, $K$ factors were also revised commencing July 1,1975 . The par price was raised to 8.31 per barrel, equal to the agreed Edmonton Terminal price. The result of these adjustments is that the royalty on 4,000 barrels of oil other than new oil is now 1,541 barrels or $38.5 \%$ of production and on new oil it is 1,114 barrels or $27.9 \%$ of production. The Alberta government is back to taking nearly the same percentage cut but the oil companies are able to absorb it because of the higher price. The royalty on new oil is still substantially higher than the old $1 / 6$ maximum, but it is an incentive to development of new oil because it is still substantially below the royalty on old oil, and because the higher prices provide greater revenues.

The only substantive difference between the Minerals Taxation Act, 1972 and the Freehold Minerals Taxation Act is that the definition of mineral right under $\mathrm{S} 1(\mathrm{k})$ of the Mineral Taxation Act, 1972 included interests granted under a Crown lease whereas the definition of a mineral right under $\mathrm{S} 1(\mathrm{~h})$ of the Freehold Mineral Taxation Act is restricted to estates in fee simple in a mineral. Other than that, the statutes are similar in procedure and effect. Section 6 of the Freehold Mineral Taxation Act states that "Every mineral right is liable to assessment and taxation in accordance with this Act." Section 7 sets out the procedure for assessment. Sections 11 and 12 set up the procedure for appealing an assessment. Section 14 provides for the levy of tax on the assessed dollar value of the minerals remaining in the ground. Section 16 provides for an exemption from tax where the assessed value is below a certain level. Section 20 provides for the vesting of title to the minerals in the Crown upon failure of the registered owner to pay taxes.

Alberta Regulation 357/73 filed December 20, 1973 accompanies the Freehold Mineral Taxation Act and establishes the regulations for its application to Petroleum in Part I and to Natural Gas rights in Part II. 